\title{
Main Streaming of Nus Crops-A Felt Need for Nutrition and Health Security
}

\author{
S.B. Dandin
}

\begin{abstract}
Large number of people all over the world in general and in developing countries in particular are suffering either from malnutrition or from undernutrition. More than $50 \%$ of children are reported to have underweight, low BMI and are stunted. The main reason being attributed is consumption of food derived out of very few cereals and meat without the required nutrition elements namely, minerals, vitamins and enzymes. Shrinkage in food basket is mainly due to erosion of biodiversity and non-cultivation of variety of crops in general and fruits and vegetables in particular which are the source of vitamins and minerals besides several other health supporting constituents. Because of this reason, neglected and underutilized species are gaining importance. Though the number of such crops is very large, few of the important crops which provide a balanced nutrition for health security are discussed in this paper.
\end{abstract}

Keywords-Food basket, NUS Crops, Nutrition, Security, nutritional composition

\section{INTRODUCTION}

Currently across the world, 868 million people are under nourished and 195 million children under five years of age are stunted. Undernutrition jeopardizes children's survival, health, growth and development, and it slows national progress towards development goals (4). It also stunts educational attainment and productivity, with widespread, long-term adverse implications for income and economic growth in the country. The main reasons attributed for undernutrition and mall nutrition all over the world is narrow food basket with very few staple food items namely rice, wheat, maize, potato, tomato and two or three animal proteins. As a result of such monotonous food habit, people get calories but deprived of vitamins, minerals and other essentials needed for good health.

The Agricultural biodiversity (ABD) baseline survey conducted by Bioversity international on of crop, diet and market to understand the intrinsic relationship between the available crop and wild plant biodiversity, the diet and market diversity in the three states of India covering six districts and 15 villages and 874 families. The study has revealed that, Continuous loss of agricultural as well as tree biodiversity has resulted in narrowing the food basket which has intern

Manuscript received Decemeber 12, 2015.

Dr.S.B.Dandin is with Bioversity International,Southern center of Sub-regional office for South Asia, Bangalore, India. limiting the dietary choice. As result, most of the population in general and women and children in particular are found either undernourished or Malnurished. This is also because of the market situation where very limited commodities are available. Further the government supportive policy to promote very few

staple crop species has forced the consumer to eat what is easily and cheaply available. To overcome the situation mainstreaming of NUS crops is imperative.

Underutilized and neglected species (NUS) crops are being recognized as "crops of the future" because of their multiple benefits such as high neutraceutical values, medicinal properties, climate resilience etc. Though the importance of these crops was well recognized in traditional system of agriculture, because of the monoculture practices of very few staple crops, their role in nutrition security was sidelined such as those of minor millets, root and tuber crops etc. NUS are found widely distributed in both the hemispheres covering tropical, subtropical and to some extent semi temperate regions of the world (2). However, they are found more dominantly in the tropical and subtropical forests in wild/semi domesticated conditions. Our early generation has recognized their importance and used to consume, grow and conserving them since centuries, thus have played a major role in their conservation. In majority of the rural areas, these species found grown in front and backyards of the dwelling places and also on the farm lands for the restricted family use. They remained as neglected / underutilized because of the following reasons:

1) Under estimation of their potential use and non-availability of botanical description

2) Poor income rendering them economically not viable for commercial cultivation.

3) Restricted distribution to a small geographical area especially in and around their center of origin.

4) Consumed by very small population especially by tribals / local inhabitants only in local areas.

5) Deprived of modern processing and postharvest technical know how

6) Inadequate research on these crops on improvement, multiplication, cultivation, nutritional composition analysis etc.

7) Promotion and popularization of very few fruit crops as staple food.

8) Fast disappearances of ecosystem and habitat destruction leading to disappearance of inter specific and intra specific variability and in turn specie themselves. 
9) Lack of marketing and promotion policy support for popularization of these crops

\section{0) Stigma attached as 'foods of the poor}

Among all the underutilized/neglected species (NUS), vegetables and fruits occupy prominent place because of their abundant occurrence, wider distribution and larger number besides their importance as a source of high amount of nutrients. There are totally 39 species belongs to 94 genera of 42 families. However, as many as 261 species belonging to 106 genera and 45 families including some of the temperate underutilized fruit crops are being cultivated in a small area by small and marginal farmers/tribals or some of them are still found in semi- domesticated conditions (1). As stated earlier, because of the large scale popularization of very few vegetable and fruit crops, NUS remained orphan and not attracted the attention of the researchers, extension agencies and policy makers.

\section{IMPORTANCE OF NUS CROPS}

1) They are found harboring nutritionally important elements.

2) Due to increased food and nutritional insecurity

3) Their climate resilient nature

4) Hardy crops adoptable to wider /harsh ecological conditions

5) Rich in neutraceutical values

6) Some of them are reported as a good source of herbal medicine for curing important ailments

7) Few of these species are also reported to be the good source of industrial raw material.

Jack, Custard apple, Garcinia, Java plum (Jamun), Ber, Tamarind, Java apple (Rose apple), Drumstick, Taro Sweet potato' lemons etc., are commonly grown around the dwelling houses. This is mainly because of their multipurpose use. Species belonging to the genus Garcinia, Morus, etc., have been used to extract industrial products. In Annonaceae family, all the five species are found cultivated in backyards or in the kitchen gardens and serve as a rich source off seasonal edible fruits besides, Annona muricata which is exploited as a source of medicine is used for curing cancer. The details of some of the important NUS are discussed in this paper. Nutritional composition of these selected crops is given in Table-1,1(a), \&1(b)

1. Jack (Artocarpus heterophyllus) High yielding fruit species with very rich nutrition value. Several food products are being prepared and consumed from young fruits, mature fruits and seeds. There are four species with few identified varieties as a rich source of carbohydrate, starch, sugar, Vit-A. Crop can be grown on marginal lands and yield good income. Preparations out of both young and mature fruits are highly valued and fetch good income to processing industry. Ten specific health benefits namely fat free calorific value, Vitamin A, readily digestible sugars, the fruits are known for their distinct sweet and fruity aroma reported to be contributed by esters and alcohols. The flake is starchy, fibrous, rich source of vitamin $\mathrm{C}$ and $100 \mathrm{~g}$ of edible flake provides about 95 calories. The seeds are rich source of starch and protein.
Every part of the plant has distinct uses and the wood has got lot of timber value.

The jackfruit flakes are used in many preparations like jams, jelly, chips, papads and many other products for which technologies have already been standardized by different institutions. Minimal processing techniques and standards have been developed. Fresh green unripe jackfruits are a delicacy in South Indian cuisine and many culinary preparations with flake of immature fruits and seeds are in vogue.

2. Avonla (Phyllanthus emblica): Native to tropical S.E. Asia and is now distributed through-out India and planted in public parks. Nutritional composition of the fruit is Moisture (\%) 81.2, Fat (\%) 0.10, Fiber (\%) 3.4, Minerals (\%) 0.7, Carbohydrates (\%)14.0, Proteins (\%) 0.5, Calcium (mg/100g) 50.0, Iron (mg/100g) $0.5 \mathrm{~g}$, Phosphorus $(\mathrm{mg} / 100 \mathrm{~g})$ 20.0, Vit-C (mg/100g) 600.0, 0.2mg nicotinic aid, Energy KJ/100g 59.0. Gallic acid present in the fruit has antioxidant property. Fruits are commonly used in the preparation of Chavanaprash, Tripala choorna and other ayurvedic medicines. Being rich source of vitamin $\mathrm{C}$, avonla is helpful in curing scurvy problems of teeth gums, eyes and stomach. Fresh fruits are also used in the preparation of preserve, pickle, chutney etc. Dry avonla powder is said to be superior than the synthetic vitamin C in treating diarrhea, dysentery, jaundice, anemia, bronchitis and cough.

3. Jamun/ Jewish plum (Syzygium cumini): A perennial tree found distributed / introduced to many Asian countries. Plants can be grown in wide range of soils and best suited for marginal lands. Fruit is the good source of iron, sugar, minerals protein \& carbohydrates. Moisture 83.7-85.8g, Potassium 55mg, Protein 0.7-0.129g, Copper $0.23 \mathrm{mg}$, Fat $0.15-0.3 \mathrm{~g}$, Sulfur 13mg, Crude Fibre 0.3-0.9g, Chlorine 8mg, Carbohydrates 14.0g, Vitamin A 80 I.U., Ash 0.32-0.4g, Thiamine $0.008-0.03 \mathrm{mg}$, Calcium $8.3-15 \mathrm{mg}$, Riboflavin $0.009-0.01 \mathrm{mg}$, Magnesium 35mg, Niacin $0.2-0.29 \mathrm{mg}$, Phosphorus 15-16.2mg, Ascorbic Acid 5.7-18mg, Iron 1.2-1.62mg, Choline 7mg, Sodium 26.2mg, Folic Acid 3mcg Fully ripened fruits are eaten as fresh and can also be processed as jam, jell, squash, wine etc. fruit $\&$ seed contain anti diabetic properties and used in treating diabetic patients. Large amount of variability is found both in intra and inter specific level. Some of the wild species holds promise to be exploited for the nutrition and medicinal values.

4. Ber (Ziziphus mauritiana) Lam. Is supposed to be a native of India and Ziziphus jujube is native to China. Indo-Malayan region including Myanmar is considered the home of Ber. Commonly occurs in drier parts of India namely; Rajasthan, Gujarat, U.P, M.P and Western Peninsula. Widely occurs in thorny scrub jungles. Ber is also introduced to; Australia, Israel, Middle East and other African countries. Pulp contents $93-97 \%$, Moisture $81 \%$, TSS $13-20 \%$, Total sugar $4.9-12.4 \%$, Non reducing sugar 2.2-8.4\%, Ascorbic acid $66-133 \mathrm{mg} / 100 \mathrm{~g}$, Fat \% 0.10, Carbohydrates \% 12.8, Proteins (\%) 0.8, Calcium (mg/ 100g) 30.0, Iron (mg/ $100 \mathrm{~g}$ ) 800.0, Phosphorus (mg/ 100g) 30.0, Vit-A IU/ 100g 70-100, Vit-C (mg/ 100g) 500-750.Ber fruits are mostly used as fresh. 
Fruits are also processed and dehydrated. Delicious murabba and candy are prepared out of fruits after processing. Attempts are also being made to prepare jam and wine from the fruits of Ber.

5. Custard apple (Annona squamosa) Annona: Genus Annona has five species and all are edible. Among them, A. squamosa (Sweet sop) is an important table fruit and also used in ice cream industry. A. muricata (Sour sop) is found effective in cure of the cancer. Other three species A. atemoya, A. cherimola \& A. glabra are also produce edible fruits. Moisture (\%) 76.0, Fat \% 0.6, Fiber \% 1.4, Carbohydrates \% 20.8, Proteins (\%) 1.9, Ascorbic acid mg/100g 35-90mg, Calcium (mg/100g) 17.0, Iron $(\mathrm{mg} / 100 \mathrm{~g})$ 0.3, Phosphorus $(\mathrm{mg} / 100 \mathrm{~g})$ 54.0, Potassium $(\mathrm{mg} / 100 \mathrm{~g})$ 142.0, Magnesium (mg/100g) 22.0, Riboflavin mg/100g 0.1, Niacin mg/100g 0.9 , Thiamin $\mathrm{mg} / 100 \mathrm{~g} \mathrm{0.1}$, Energy KJ/100g 360.0. Seeds of most of these species contain anti-insect property and locally used for control of pests. Yellowish green heart shaped edible fruits are covered with rounded, fleshy tubercules representing loosely cohering carpel and highly valued for its sweet taste. Green leaves yield essential oil. Powdered seeds and leaves possess insecticidal properties. Now the fruit is used in ice-cream industry. Apart from fresh consumption, its pulp can be processed to prepare products like Pastries, chocolates, ice cream mixed fruit jam.

6. Drum stick (Moringa olefera): A perennial multi-purpose tree mostly grown in home gardens of India, Sri Lanka, Indonesia, Vietnam, Thailand, Malaysia, Philippines etc. Almost all parts of tree i.e., young leaves, flowers, fruits and seeds are used as food besides, for medicinal purposes. Rich in Vit-A, C and iron, calcium \& potassium besides, protein. Plants produce pods throughout the year and serves as one of the most sought after vegetable. Several dishes are prepared both alone or in combination. Leaves are good source of iron and fibre and found very good for women \& children who suffer from anemic disorder. Crop can be grown in wide range of soils with varied fertility status and climatic conditions.

7. Sweet Potato (Ipomoea batatas): Is a widely adopted root crop grown in large number of countries. These exist large variability in yield, colour, size \& shape of tuber. The crops offer immense food potential as a rich source of carbohydrate \& vitamins with a potential to fight against Vit-A deficiency. Orange fleshed varieties are rich in B carotenes and purple fleshed varieties are rich in anthocyanins two important anti-oxidants are known to fight against cancer $\&$ chronic heart diseases. Two important antioxidants thought to prevent chronic heart diseases and cancer. Significant amount of essential minerals are found in sweet potato including manganese, copper, iron and potassium. Sweet potatoes are also of industrial importance for starch and alcohol production. Cultivars and varieties show wide adaptability \& grows well in marginal land and could be a candidate species for climate resilience.

8. Taro (Colocasia esculenta): Taro originated in Southeast Asia including India and Malaysia. There is considerable evidence that taro and other edible aroids were distributed from east India to Formosa and the Solomon Islands. Taro is the sixth important crop among the tuber crops and ranks 14th among staple vegetable crops thus significant in the global food system. Taro coms and carmels provide for carbohydrates and have a similar nutritional value as that of potatoes. In comparison to their protein content is slightly higher. Carbohydrates and proteins of taro underground parts are hypoallergenic and easily digested. Further, taro contains minerals, vitamin C, vitamin B1 and B2 and niacin. Taro leaves are rich in protein; nutritional value is commonly compared with spinach. Taro is recommended for gastric patients and taro flour is a good baby food. In Hawaii and Polynesia, a fermented product prepared from taro is very popular. The pressure cooked taro corms after being passed through strainer are allowed to ferment giving an acidic product called 'poi'. In Africa, the corm paste prepared from the cooked taro is taken in the name 'fufu'. In India it is used as vegetable and for the preparation of slices and chips

TABLE-I: NUTRITIONAL VALUES OF SOME OF THE NUS FRUIT SPECIES

\begin{tabular}{|c|c|c|c|c|c|c|c|}
\hline Crop & $\begin{array}{l}\text { Moistu } \\
\text { re }(\%)\end{array}$ & $\begin{array}{l}\text { TSS } \\
\text { (0Brix) }\end{array}$ & $\begin{array}{l}\text { Fat } \\
\%\end{array}$ & $\begin{array}{l}\text { Fibe } \\
\text { r \% }\end{array}$ & $\begin{array}{l}\text { Mine } \\
\text { rals } \\
\%\end{array}$ & $\begin{array}{l}\text { Carb } \\
\text { ohydr } \\
\text { ates } \\
\%\end{array}$ & $\begin{array}{l}\text { Protein } \\
\text { s }(\%)\end{array}$ \\
\hline Ber & 81 & $13-17$ & 0.1 & -- & - & 12.8 & 0.8 \\
\hline Fig & & - & 1 & - & - & 69 & 4 \\
\hline Aonla & 81.2 & - & 0.1 & 3.4 & 0.7 & 14 & 0.5 \\
\hline $\begin{array}{l}\text { Jack } \\
\text { fruit }\end{array}$ & 77.2 & - & 0.1 & 1.1 & 0.8 & 18.9 & 1.9 \\
\hline $\begin{array}{l}\text { Sweet } \\
\text { sop }\end{array}$ & 76 & - & 0.6 & 1.4 & & 20.8 & 1.9 \\
\hline Bael & 61.5 & - & 0.4 & & 1.7 & 31.8 & 1.8 \\
\hline Jamun & $\begin{array}{l}84.5- \\
86.4 \\
\end{array}$ & $\begin{array}{l}9- \\
11.5\end{array}$ & 0.1 & - & - & - & $\begin{array}{l}0.53- \\
0.65 \\
\end{array}$ \\
\hline $\begin{array}{l}\text { Sweet } \\
\text { potato }\end{array}$ & - & - & - & $0^{3 .}$ & - & - & - \\
\hline $\begin{array}{l}\text { Drum } \\
\text { stick }\end{array}$ & - & - & $\begin{array}{r}0 \\
.59\end{array}$ & - & - & - & 2.3 \\
\hline Taro & 73.1 & - & 0.19 & - & - & 31.0 & 21.1 \\
\hline
\end{tabular}

TABLE I(A): NUTRITIONAL VALUES OF SOME OF THE NUS FRUIT SPECIES

\begin{tabular}{|c|c|c|c|c|c|c|}
\hline Crop & $\begin{array}{l}\text { Ascorbi } \\
\text { c acid } \\
\text { mg/ } \\
100 \mathrm{~g}\end{array}$ & $\begin{array}{l}\text { Calci } \\
\text { um } \\
(\mathbf{m g} / \\
\mathbf{1 0 0 g})\end{array}$ & $\begin{array}{l}\text { Iron } \\
\text { (mg/ } \\
100 \mathrm{~g})\end{array}$ & $\begin{array}{l}\text { Phos } \\
\text { phor } \\
\text { us } \\
\text { (mg/ } \\
\text { 100g } \\
\text { ) }\end{array}$ & $\begin{array}{l}\text { Potassiu } \\
\mathrm{m}(\mathrm{mg} / \\
100 \mathrm{~g})\end{array}$ & $\begin{array}{l}\text { Magnesiu } \\
\text { m (mg/ } \\
100 \mathrm{~g})\end{array}$ \\
\hline Ber & $66-110$ & 30 & 800 & 30 & -- & -- \\
\hline Fig & & 200 & 4 & - & - & - \\
\hline Aonla & - & 50 & 0 & 20 & - & - \\
\hline $\begin{array}{l}\text { Jack } \\
\text { fruit }\end{array}$ & - & 20 & 500 & 30 & - & - \\
\hline $\begin{array}{c}\text { Sweet } \\
\text { sop }\end{array}$ & $35-90$ & 17 & 0.3 & 54 & 142 & 22 \\
\hline Bael & - & - & - & - & - & - \\
\hline Jamun & - & 20 & 100 & 10 & & - \\
\hline $\begin{array}{l}\text { Sweet } \\
\text { potato }\end{array}$ & - & 30 & - & & 337 & - \\
\hline $\begin{array}{c}\text { Drum } \\
\text { stick }\end{array}$ & - & 18.0 & 22.0 & $\begin{array}{r}2 \\
6.0 \\
\end{array}$ & & \\
\hline Taro & - & 0.03 & 1.7 & - & - & - \\
\hline
\end{tabular}


TABLE-I(B): NUTRITIONAL VALUES OF SOME OF THE NUS FRUIT SPECIES

\begin{tabular}{|c|c|c|c|c|c|c|c|}
\hline Crop & $\begin{array}{l}\text { Ribofl } \\
\text { avin } \\
\mathrm{mg} / \\
\mathbf{1 0 0 g}\end{array}$ & $\begin{array}{l}\text { Niac } \\
\text { in } \\
\mathrm{mg} / \\
100 \mathrm{~g}\end{array}$ & $\begin{array}{l}\text { Vit- } \\
\text { A } \\
\text { IU/ } \\
\text { 100g }\end{array}$ & $\begin{array}{l}\text { Thi } \\
\text { ami } \\
\text { n } \\
\text { mg/ } \\
\text { 100 } \\
\text { g }\end{array}$ & $\begin{array}{l}\text { B } \\
\text {-car } \\
\text { oten } \\
\text { e } \\
\text { mg/ } \\
100 \mathrm{~g}\end{array}$ & $\begin{array}{l}\text { Vit-C } \\
(\mathrm{mg} / \\
100 \mathrm{~g})\end{array}$ & $\begin{array}{l}\text { Energy } \\
\mathrm{KJ} / 100 \mathrm{~g}\end{array}$ \\
\hline Ber & - & - & $\begin{array}{l}70- \\
100\end{array}$ & - & - & $\begin{array}{l}500- \\
750\end{array}$ & - \\
\hline Fig & - & - & 100 & 0.1 & - & - & 260 \\
\hline Aonla & - & - & - & - & - & 600 & 59 \\
\hline Jack fruit & - & - & 540 & 30 & - & - & 84 \\
\hline Sweet sop & 0.1 & 0.9 & & 0.1 & & & 360 \\
\hline Bael & 1.19 & 1.1 & & 0.13 & 55 & 8 & \\
\hline Jamun & - & - & $\begin{array}{l}73- \\
100\end{array}$ & - & - & $\begin{array}{c}30.30- \\
40.7\end{array}$ & 83 \\
\hline $\begin{array}{l}\text { Sweet } \\
\text { potato }\end{array}$ & - & - & 1417 & - & - & 2.4 & - \\
\hline Drum stick & - & - & 151 & - & - & 86 & - \\
\hline Taro & 40.0 & - & - & - & - & $\begin{array}{l}0.0 \\
9\end{array}$ & - \\
\hline
\end{tabular}

\section{CONCLUSION}

Biodiversity of the planet is under treat due to several anthropogenic acuities on one hand and cultivation of very few crops as staple food source on the other. As a result, people all over the world are consuming simple and energy supplying few species daily. This has resulted in an increased number of malnourished and undernourished population and became the burden to the society. Only possible way to mitigate the situation is to widen the food basket with variety of fruits and vegetables as insurance for health and nutrition insecurity. Towards this goal, consumption, commercialization, cultivation and conservation of species having good nutritional composition is imperative. Based on this concept it is necessary to identify crops among the NUS to bring them to the mainstream of cultivation and made available for day-to-food basket.

\section{ACKNOWLEDGEMENT}

The Author is thankful to Bioversity International for all the support and encouragement.

\section{REFERENCES}

[1] Arora R.K. (2014) Diversity in underutilized plant species-an Asia-Pacific Persepctive Bivoversity International, New Delhi, India,203p

[2] Dandin S.B. and Mathur P. (2015), Underutilized fruit crop of tropical and subtropical regions of India. Edt. Ravindran. C, Kalaselvan A and. Monamani K. Proceedigs of $3^{\text {rd }}$ international symposium on underutilized plant species. 12-29 2015

[3] James George and Sunita S. (2015) Tuber crops of India.AICRP ON TUBER CROPS, ICAR, CTCRI, Thiruvanathapurum, India. P 381

[4] Ruth charrondier U, (2015), initiatives linking biodiversity to nutrition programme, Abstract book, $11^{\text {th }}$ IFDC pre conference workshop IV, $2^{\mathrm{ND}}$ Nov, 2015 NIN Hyderabad, India 